\title{
Distance Learners' Attitude towards Technological Innovations
}

\author{
Zubia Noreen \\ Ph.D Scholar, Department of \\ Distance and Non formal \\ Education \\ Allama Iqbal Open University \\ Islamabad Pakistan
}

\author{
Mian Baqar Qureshi \\ Ph.D Scholar, Department of \\ Distance and Non formal \\ Education \\ Allama Iqbal Open University \\ Islamabad Pakistan
}

\author{
Nuzhat Kalsoom \\ Ph.D Scholar, Department of \\ Distance and Non formal \\ Education \\ Allama Iqbal Open University \\ Islamabad Pakistan
}

\begin{abstract}
In $21^{\text {st }}$ century emerging technologies are sprinkling at extraordinary speed and these innovations have turned this world into a global village. In the field of distance education these innovations have bridged the distance of all learners to a large extent. Technological innovations have great influence on all aspect of our lives personal, professional and educational as well. In the field of education distance learning is a growing trend where there is distance between teacher and student bridged with media, and in this age of science innovative technologies are the best media to cover this gap. This effort was made to point out and discuss the technological innovations in Pakistan and the attitude of distance learners towards it. It was survey study. Population of the study consisted of all departments of education at AIOU. Survey was conducted through questionnaire for MS/M.phil students. The study revealed that majority of the distance learners at MS/Mphil level have positive attitude towards latest technology but they need proper training to be aware of and comprehend the benefits of educational technological innovations so the study recommended that for the easy and cheaper access to internet technology, a holistic policy may be devised with the collaboration of PTCL. Cheaper and in installments laptop computers may be provided to distance learners with the cooperation of various national and multi national companies. Besides, the provision of computer paraphernalia, training aspect may be focused on priority basis so that optimum benefits may be attained from these technological gadgets. Latest softwares may be used to facilitate distance learners. Tutors and distance learners should use internet and latest software continuously to improve teaching learning process in distance education system.
\end{abstract}

\section{KEYWORDS}

Distance learners, Attitude, Technological innovations.

\section{INTRODUCTION}

Technological innovation is the process through which new or improved technologies are developed and brought into widespread use. Technology has revolutionized all walks of life and education is not exceptional. As far as distance education is concerned latest technologies have brought a big change in this mode of education. Basically in distance education system there is distance between students and teachers and institution which can be filled with the usage of different media. Now latest technology has filled that gap between student and teachers in distance education system. Now a distance learner can easily communicate with the teachers and peers with the help of advance technology, now education can be acquire anywhere and anytime because of technological innovations. Advance technology has made the distance learning more interesting and convenient for students. In advance countries distance educators and students have been accepted this new change and made that process more flexible and comfortable. This paper examines the attitude of distance learners of Allama Iqbal Open University of Pakistan towards technological innovations and need of this advance technology for distance learners. This paper also examines the access of distance learners to most recent technology and softwares.

\section{DISTANCE LEARNERS AND THEIR NEEDS}

Distance learners are generally far away from the institution and instructors; and they feel loneliness so their needs are different from the students of formal education system. For the successful and effective results they need proper guidelines and support from the organization and trainers as well. Garrison (1990, p.103) states that, "the majority of distance education is concerned with meeting the educational needs of adults". According to Holmberg (1986, p.123) "distance teaching will support student motivation, promote learning pleasure and effectiveness if offered in a way to make the study relevant to the individual learner and his/her needs". Distance learners need to be in touch with the tutor for educational help. To get rid from the isolation they want to develop contacts with peers. Students wish for alternate resources along with study guides. They desire more interactive ways of communication with instructor and mates other than occasional face to face meetings. Distance learners wish to get latest knowledge to compete with the students of formal education system and to meet the needs of the distance learners the only solution is the usage of growing technology in the field of distance education, with the help of advance technology the isolation of the distance learner can be reduced and they can get many other sources for obtaining knowledge.

\section{TECHNOLOGY}

Technology can have positive and negative impacts on individuals, society, and the environment. Humans have the capability and responsibility to constrain or promote technological development. In the field of education technology affects the attitude of the learners. "Technology is the process by which humans modify nature to meet their needs and wants. Most people, however, think of technology in terms of its artifacts: computers and software, aircraft, pesticides, water-treatment plants, birth-control pills, and microwave ovens, to name a few but technology are more than these tangible products. Technology includes the entire infrastructure necessary for the design, manufacture, operation, and repair of technological artifacts, from corporate 
headquarters and engineering schools to manufacturing plants and maintenance facilities". (http://wiki.answers.com/Q/What is technology retrieved on 6-4-2012)

\section{TECHNOLOGY IN EDUCATION}

Technology has great impact on education, its not only assist teachers in their teaching process but improving the teaching procedure as well. The students also get the advantage from the technology; learning practice is now more attentiongrabbing with the usage of technology. "The pace of change brought about by new technologies had a significant effect on the way people live, work, and play worldwide. New and emerging technologies challenge the traditional process of teaching and learning, and the way education is managed. Information technology, while an important area of study in its own right, is having a major impact across all curriculum areas. Easy worldwide communication provides instant access to a vast array of data, challenging assimilation and assessment skills. Rapid communication, plus increased access to IT in the home, at work, and in educational establishments, could mean that learning becomes a truly lifelong activity - an activity in which the pace of technological change forces constant evaluation of the learning process itself".

The importance of technology in education is as following:

- $\quad$ access to variety of learning resources

- immediacy to information

- anytime learning

- $\quad$ anywhere learning

- collaborative learning

- multimedia approach to education

- authentic and up to date information

- $\quad$ access to online libraries

- teaching of different subjects made interesting

- educational data storage

- distance education

- $\quad$ access to the source of information

- multiple communication channels-e

- mail,chat,forum,blogs,etc

- $\quad$ access to open courseware

- better accesses to children with disabilities

- reduces time on many routine tasks

(http://wikieducator.org/Need_and_Importance_of_Infor mation_Technology_in_Education retrieved on 6-4$\underline{2012) .}$

\section{DISTANCE EDUCATION}

According to Dr. Kathryn Barker. (1999). distance education is a teaching / learning environment characterized by the separation of teacher and learner during at least the majority of the instructional process; the influence of an educational organization, including some form of student evaluation; and the use of educational media and technologies to unite teacher and learner, to carry course content and provide two-way interaction. In distance learning, students can be anywhere and a teacher will reach them to transmit knowledge in traditional ways, which commonly means lecturing with oneor two-way video and audio transmitted by phone line, cable $\mathrm{TV}$, or satellite. In the last decade, distance education has developed in two major directions: "the individual flexible teaching model and the extended classroom model' (Rekkedal and Dye, 2007). The former allows students to start the class at any time, study in isolation and communicate with instructors and classmates through asynchronous tools. The latter organizes students into groups, requires them to meet at local study centre, and allow them to use interactive technologies such as video conferencing to interact (Rekkedal \& Dye, 2007).

\section{TECHNOLOGY BASED DISTANCE LEARNING}

Technological advances have created a paradigm shift in education and distance education as well. The definition of distance learning, as described by James Morrison (1996), who states that telecommunications, software, and the Internet eliminate walls and boundaries. In addition, he states that an increasing number of students want and need non-traditional, flexible schedules. In fact, the explosion of information technologies has brought learners together by erasing the boundaries of time and place for both site based and distance learners. Research in distance education reflects the rapid technological changes in this field. Ozgur (2007).

In today's competitive world, the success of the distance education system depends upon innovations, which would increase the efficiency and quality of the system. Technology based distance education is termed as the delivery of courses/programmes through different means of technology. In distance education, technology is used to communicate with the learner instead of depending mainly on the teacher lecturing. Each and every means of technology that is used in distance education will work towards effective communication of information. Technology based distance education will yield more benefits to the learner who can access it at their own pace, time and geographical location.

In the field of distance education most of the institutions adopt different modes of delivery starting from print media as first level development to the present high tech video conferencing and computer teaching as a fifth level development. The modes of delivery have undergone different changes over the years and the institutions are competing to become more learner centered and assisting the learners with more supplementary modes of delivery. Now, the trend is towards the use of new technologies in distance education as a supplementary to the existing systems. (http://www.col.org/pcf3/papers/pdfs/kuruba_gangappa.pdf retrieved on 7-4-2012).

\section{TECHNOLOGICAL INNOVATIONS IN DISTANCE EDUCATION}

Technology innovation is the process through which new (or improved) technologies are developed and brought into widespread use. In the simplest formulation, innovation can be thought of as being composed of research, development, demonstration, and deployment, although it is abundantly clear that innovation is not a linear process - there are various interconnections and feedback loops between these stages, and often even the stages themselves cannot be trivially disaggregated. Innovation involves the involvement of a range of organizations and personnel (laboratories, firms, financing organizations, etc.), with different institutional arrangements underpinning the development and deployment of different kinds of technologies; contextual factors such as government policies also significantly shape the innovation process. (http://www.eoearth.org/article/Technological_innovation retrieved on 7-4-2012). 
Information and Communication Technology (ICT) touches all parts of life including education. The impact of ICT in education can be felt strongly by observing the uses of ICT tools, such as multiple media, in teaching. These ICT tools support the predominant print media being used by the distance learning. The current multiple media being used in distance education system include audio and video cassette tapes, CD-ROM, interactive radio, television, teleconferencing, videoconferencing, online teaching through multimedia and recently, instruction delivery through iPods. Another important ICT tool, the mobile, is showing good promise as a means of instructional delivery to the ODL learner.

(http://webserver.ignou.ac.in/NCIDE/Report250209.pdf.)

According to John Bingham, Teresa Davis, Cathy Moore (2000)" Due to the technological advances of the recent past, a great deal of excitement and hope has been generated for the use of distance learning in education. Rapid advances in computer and telecommunications capabilities have made possible the development of learning modules that include elements such as video transmission, e-mail, the internet, and the World Wide Web. These modules can function either as components of the learning process or as the basis for instruction. The progression of long distance learning from pen-pals, college correspondence courses, teleconferencing over speaker phones, teleconferencing via modem, transporting still pictures along with interactive audio, to the latest technology of two-way, full audio, full video communication has implications for public education".

E-learning is one of the main latest technologies. The growth of e-learning is directly related to the increasing access to information and communications technology, as well its decreasing cost. The capacity of information and communications technology to support multimedia resourcebased learning and teaching is also relevant to the growing interest in e-learning. Growing numbers of teachers are increasingly using information and communications technology to support their teaching. The contemporary student population (often called the "Net Generation", or "Millennials") who have grown up using information and communications technology also expect to see it being used in their educational experiences (Oblinger and Oblinger, 2005).

According to Shaheen E. Lakhan and Kavita Jhunjhunwala (2008, p.2) "Educational institutions have rushed to put their academic resources and services online, bringing the global community onto a common platform and awakening the interest of investors." Despite continuing technical challenges, online education shows great promise. Open source software offers one approach to addressing the technical problems in providing optimal delivery of online learning. Open source refers to both the concept and practice of making program source code openly available. Users and developers have access to the core designing functionalities that enable them to modify or add features to the source code and redistribute it. Extensive collaboration and circulation are central to the open source movement".

In distance education system mobile learning is emerging trend. Mobile learning aims to make the learning process more flexible, accessible and personalized. Mobile learning is about exploring new ways to use mobile environments to improve access to information for the learners who want to update their knowledge continuously to satisfy the everyday demands of their jobs. With mobile wireless network or service in mobile wireless devices, users can access network information anytime, anywhere. (Hahn,
2008). for example, people can carry wireless laptops anytime, anywhere and can access a network in public places, such as an airport and a library. In addition, handheld devices can be carried and connected to a network anywhere, anytime.

\section{DEFINITION OF ATTITUDE}

Attitudes are the views of a person whether positive or negative. Le Roux (1994:06) defines attitude to be "a positive or negative emotional relationship with or predisposition toward an object, institution or person. According to Brecker and wiggins(1991:137) enduring non verbal features of social and physical world, and they are acquired through experience and exert a directive influence on behaviour . Allport (1935) defined an attitude as a mental or neural state of readiness, organized through experience, exerting a directive or dynamic influence on the individual's response to all objects and situations to which it is related. A simpler definition of attitude is a mindset or a tendency to act in a particular way due to both an individual's experience and temperament. Typically, when we refer to a person's attitudes, we are trying to explain his or her behavior. Attitudes are a complex combination of thing we tend to call personality, beliefs, values, behaviors, and motivations. After these definitions we can say that attitude is an emotion which can be influenced on the behavior of human beings.

Allama Iqbal Open University brings in technology to enrich the students learning process : Allama Iqbal Open University (AIOU) is planning significant technological changes to keep the students informed about assignment marks, improve e-learning facility and increase tutor-pupil interaction through latest technologies and softwars. In this paper effort has been made to find out the attitude of distance learners of Allama Iqbal Open University (Pakistan) towards technological innovations. These innovations have great impact on the teaching and learning process in distance education system. All over the world students who are learning from distance education system have positive attitude towards latest technology and universalities are adopting emerging technologies and softwares in their teaching learning process.

\section{OBJECTIVE OF THE STUDY WERE TO:}

- discuss the importance of advance technologies in distance education system.

- explore the access of latest technology to distance learners.

- assess the attitude of distance learners towards technological innovations.

\section{PROCEDURE OF THE STUDY}

Questionnaire was used as instrument for this study; in the questionnaire three point likert scale was developed for collecting the data from the population of the study. For purpose of data collection 130 MS/ M.phil Scholars of AlOU

was taken into account. The questionnaire was developed on three point likert scale yes, no and I don't know. 


\section{DATA ANALYSIS}

Table 1: Discuss the importance of advance technologies in distance education system.

\begin{tabular}{|c|c|c|c|c|c|c|}
\hline $\begin{array}{l}\text { S. } \\
\text { No }\end{array}$ & Statements & Yes & $\begin{array}{l}\text { I don't } \\
\text { know }\end{array}$ & No & $\%$ & Mean \\
\hline 1 & $\begin{array}{l}\text { It is necessary for } \\
\text { distance learners to } \\
\text { learn working with } \\
\text { latest technologies. }\end{array}$ & 112 & 12 & 6 & 86.1 & 2.81 \\
\hline 2 & $\begin{array}{l}\text { For educational } \\
\text { guidance student } \\
\text { want to interact } \\
\text { with the teachers } \\
\text { thorough web.2 } \\
\text { technology. }\end{array}$ & 130 & 0 & 0 & 100 & 3.00 \\
\hline 3 & $\begin{array}{l}\text { Contacts with } \\
\text { fellows on social } \\
\text { networks are useful } \\
\text { in distance learning } \\
\text { system. }\end{array}$ & 116 & 12 & 2 & 89.2 & 2.88 \\
\hline 4 & $\begin{array}{l}\text { Latest technological } \\
\text { sources are helpful } \\
\text { along with the } \\
\text { printed material in } \\
\text { distance learning } \\
\text { system. }\end{array}$ & 128 & 2 & 0 & 98.5 & 2.98 \\
\hline 5 & $\begin{array}{l}\text { Advance } \\
\text { technology is the } \\
\text { best facilitator in } \\
\text { teaching learning } \\
\text { process of distance } \\
\text { education. }\end{array}$ & 128 & 2 & 0 & 98.5 & 2.98 \\
\hline 6 & $\begin{array}{l}\text { Distance learners } \\
\text { desire to get latest } \\
\text { knowledge related } \\
\text { to innovative } \\
\text { technology to } \\
\text { compete with the } \\
\text { regular students. }\end{array}$ & 130 & 0 & 0 & 100 & 3.00 \\
\hline
\end{tabular}

The Table 1 shows that the maximum respondents agreed that it is necessary for distance learners to learn working with latest technologies. $100 \%$ respondents agreed that for educational guidance student want to interact with the teachers' thorough web. 2 technology and they also desire to get latest knowledge related to innovative technology to compete with the regular students. Most of the respondents agreed that contacts with fellows on social networks are useful in distance learning system and latest technological sources are helpful along with printed material in distance learning system. Many respondents agreed that advance technology is the best facilitator in teaching learning process of distance education. In all the statements percentages are over $86.1 \%$ and the mean score is more than 2.81 .
Table 2: Access of latest technology to distance learners

\begin{tabular}{|c|c|c|c|c|c|c|}
\hline $\begin{array}{l}\text { S. } \\
\text { No }\end{array}$ & Statements & Yes & $\begin{array}{l}\text { I } \\
\text { don't } \\
\text { know }\end{array}$ & No & $\%$ & $\begin{array}{c}\text { Mea } \\
n\end{array}$ \\
\hline 1 & $\begin{array}{l}\text { I have a computer } \\
\text { or a laptop. }\end{array}$ & 130 & 0 & 0 & 100 & 3.00 \\
\hline 2 & $\begin{array}{l}\text { I have fast } \\
\text { internet } \\
\text { connection for } \\
\text { my computer/ } \\
\text { laptop. }\end{array}$ & 102 & 18 & 8 & 78.5 & 2.69 \\
\hline 3 & $\begin{array}{l}\text { I have a } \\
\text { mobile/cell } \\
\text { phone. }\end{array}$ & 130 & 0 & 0 & 100 & 3.00 \\
\hline 4 & $\begin{array}{l}\text { There is a web } \\
\text { cam in my } \\
\text { computer/laptop. }\end{array}$ & 62 & 22 & 46 & 47.7 & 2.12 \\
\hline 5 & $\begin{array}{l}\text { I do video chat } \\
\text { with my tutor. }\end{array}$ & 52 & 20 & 58 & 40.0 & 1.95 \\
\hline 6 & $\begin{array}{l}\text { I do video chat } \\
\text { with my friends. }\end{array}$ & 64 & 20 & 46 & 49.2 & 2.14 \\
\hline 7 & $\begin{array}{l}\text { I connect with } \\
\text { other people of } \\
\text { the world on } \\
\text { LinkedIn. }\end{array}$ & 34 & 18 & 78 & 26.1 & 1.66 \\
\hline 8 & $\begin{array}{l}\text { I have an account } \\
\text { on facebook. }\end{array}$ & 76 & 10 & 44 & 58.5 & 2.25 \\
\hline 9 & $\begin{array}{l}\text { Skype is installed } \\
\text { in my } \\
\text { computer/laptop. }\end{array}$ & 40 & 16 & 74 & 30.8 & 1.76 \\
\hline 10 & $\begin{array}{l}\text { I use twitter for } \\
\text { connecting } \\
\text { people. }\end{array}$ & 28 & 16 & 86 & 21.5 & 1.55 \\
\hline 11 & $\begin{array}{l}\text { I am the member } \\
\text { of any digital } \\
\text { library }\end{array}$ & 56 & 22 & 52 & 43.1 & 2.03 \\
\hline 12 & $\begin{array}{l}\text { I have a } \\
\text { membership of an } \\
\text { educational group } \\
\text { on social } \\
\text { networking } \\
\text { website. }\end{array}$ & 62 & 22 & 46 & 47.7 & 2.12 \\
\hline 13 & $\begin{array}{l}\text { I often watch } \\
\text { digital TV for } \\
\text { informative } \\
\text { programs. }\end{array}$ & 38 & 16 & 76 & 29.2 & 1.71 \\
\hline 14 & $\begin{array}{l}\text { Internet is } \\
\text { activated in my } \\
\text { mobile phone. }\end{array}$ & 28 & 16 & 86 & 21.5 & 1.55 \\
\hline 15 & $\begin{array}{l}\text { I download } \\
\text { educational } \\
\text { videos from you- } \\
\text { tube. }\end{array}$ & 76 & 10 & 44 & 58.5 & 2.25 \\
\hline 16 & $\begin{array}{l}\text { I search my } \\
\text { required material } \\
\text { from educational } \\
\text { websites. }\end{array}$ & 128 & 2 & 0 & 98.5 & 2.98 \\
\hline
\end{tabular}


The Table 2 shows that $100 \%$ respondents agreed that they have computers or laptops and they have mobile/cell phones as well. Many respondents agreed that they have fast internet connection for computers/ laptops. Some students agreed that there is a web cam in their computers/laptops and they do video chat with their tutors or friends. Some students agreed that they have facebook accounts and they download educational videos from you-tube. Few respondents agreed that they use LinkedIn and twitter and they have installed skype in their computers/laptops. Few respondents agreed that they watch digital TV for informative programs and internet is activated in their mobile phones. Maximum respondents agreed that they search required material from educational websites. In all the statements percentages are over 21.5and the mean score is more than 1.55.

Table 3: Attitude of distance learners towards technological innovations

\begin{tabular}{|c|c|c|c|c|c|c|}
\hline $\begin{array}{l}\text { S. } \\
\text { No }\end{array}$ & Statements & Yes & $\begin{array}{l}\text { I don't } \\
\text { know }\end{array}$ & No & $\%$ & $\begin{array}{c}\text { Mea } \\
\mathrm{n}\end{array}$ \\
\hline 1 & $\begin{array}{l}\text { I like to write my } \\
\text { assignments on } \\
\text { computer rather } \\
\text { than hand made. }\end{array}$ & 124 & 2 & 4 & 95.4 & 2.92 \\
\hline 2 & $\begin{array}{l}\text { I prefer to call my } \\
\text { tutor on his/her } \\
\text { mobile in spite of } \\
\text { to visit institution. }\end{array}$ & 102 & 18 & 8 & 78.5 & 2.69 \\
\hline 3 & $\begin{array}{l}\text { I have mobile } \\
\text { numbers of my } \\
\text { tutors and fellows. }\end{array}$ & 62 & 22 & 46 & 47.7 & 2.12 \\
\hline 4 & $\begin{array}{l}\text { I watch } \\
\text { educational videos } \\
\text { on you-tube. }\end{array}$ & 28 & 16 & 86 & 21.5 & 1.55 \\
\hline 5 & $\begin{array}{l}\text { I send emails to } \\
\text { my teachers and } \\
\text { friends. }\end{array}$ & 52 & 20 & 58 & 40.0 & 1.95 \\
\hline 6 & $\begin{array}{l}\text { For academic } \\
\text { purpose I send } \\
\text { SMS to my } \\
\text { teachers and } \\
\text { fellows. }\end{array}$ & 64 & 20 & 46 & 49.2 & 2.14 \\
\hline 7 & $\begin{array}{l}\text { I make calls to my } \\
\text { class fellows for } \\
\text { getting educational } \\
\text { assistance. }\end{array}$ & 62 & 22 & 46 & 47.7 & 2.12 \\
\hline 8 & $\begin{array}{l}\text { I use facebook for } \\
\text { connecting people. }\end{array}$ & 76 & 10 & 44 & 58.5 & 2.25 \\
\hline 9 & $\begin{array}{l}\text { I have the } \\
\text { membership of } \\
\text { education blog. }\end{array}$ & 40 & 16 & 74 & 30.8 & 1.76 \\
\hline 10 & $\begin{array}{l}\text { I watch } \\
\text { educational videos } \\
\text { on digital } \\
\text { Television. }\end{array}$ & 28 & 16 & 86 & 21.5 & 1.55 \\
\hline 11 & $\begin{array}{l}\text { I consult digital } \\
\text { libraries for } \\
\text { obtaining } \\
\text { educational } \\
\text { material. }\end{array}$ & 56 & 22 & 52 & 43.1 & 2.03 \\
\hline 12 & $\begin{array}{l}\text { I use cell phone for } \\
\text { using internet. }\end{array}$ & 34 & 18 & 78 & 26.1 & 1.66 \\
\hline
\end{tabular}

The Table 3 shows that maximum respondents agreed that they like to write assignments on computer rather than hand made and many respondents agreed that they prefer to call tutor on his/her mobile in spite of to visit institution. Some of the respondents agreed that they have mobile numbers of their tutors and fellows. Few respondents agreed that they watch educational videos on you-tube and watch educational videos on digital television. Some of the students agreed that they send emails to the teachers and friends and SMS to teachers and fellows for academic purpose. Some of the students agreed that they make calls to class fellows for getting educational assistance and use facebook for connecting people. Few respondents agreed that they have the membership of education blog. Some respondents agreed that they consult digital libraries for obtaining educational material and few respondents agreed that they use cell phone for using internet. In all the statements percentages are over $21.5 \%$ and the mean score is more than 1.55 .

\section{FINDINGS}

Maximum respondents agreed that it is necessary for distance learners to learn working with latest technologies. $100 \%$ respondents agreed that for educational guidance student want to interact with the teachers thorough web. 2 technology and they also desire to get latest knowledge related to innovative technology to compete with the regular students. Majority of the respondents agreed that contacts with fellows on social networks are useful in distance learning system and latest technological sources are helpful along with printed material. Many respondents agreed that advance technology is the best facilitator in teaching learning process of distance education. $100 \%$ respondents agreed that they have computers or laptops and they have mobile/cell phones as well. Many respondents agreed that they have fast internet connection for computers/ laptops. Some students agreed that there is a web cam in their computers/laptops and they do video chat with their tutors or friends. Some students agreed that they have facebook accounts and they download educational videos from youtube. Few respondents agreed that they use LinkedIn and twitter and they have installed skype in their computers/laptops. Few respondents agreed that they watch digital TV for informative programs and internet is activated in their mobile phones. Maximum respondents agreed that they search required material from educational websites. Maximum respondents agreed that they like to write assignments on computer rather than hand made and many respondents agreed that they prefer to call tutor on his/her mobile in spite of to visit institution. Some of the respondents agreed that they have mobile numbers of their tutors and fellows. Few respondents agreed that they watch educational videos on you-tube and watch educational videos on digital television. Some of the students agreed that they send emails to the teachers and friends and SMS to teachers and fellows for academic purpose. Some of the students agreed that they make calls to class fellows for getting educational assistance and use facebook for connecting people. Few respondents agreed that they have the membership of education blog. Some respondents agreed that they consult digital libraries for obtaining educational material and few respondents agreed that they use cell phone for using internet.

\section{CONCLUSION AND RECOMMENDATION}

With the data description it was concluded that technological innovations for distance learners are need of the time and with the assistance of latest technologies distance learning system 
can be facilitated in a large extent. Access of Advance technology is not easy to everyone but several distance learners are using latest gadets and softwares in their education. It was also concluded that distance learners have positive attitude towards latest technologies, but they need proper training to be aware of and comprehend the benefits of educational technological innovations so the study recommended that for the easy and cheaper access to internet technology, a holistic policy may be devised with the collaboration of PTCL. Cheaper and in installments laptop computers may be provided to distance learners with the cooperation of various national and multi national companies. Besides, the provision of computer paraphernalia, training aspect may be focused on priority basis so that optimum benefits may be attained from these technological gadgets. Tutors and distance learners should use internet and latest software continuously. Teachers may be trained to effectively operate modern softwares which may be used as teaching aids. Higher order technology may be imparted on teachers as well. Website development software, methods of searching/evaluating websites, graphing calculator usage, and other specific technological devices will be addressed. Teachers will be made proficient with these tools. Students and academicians of education department may employ latest technologies and internet softwares which can be supportive in academics.

\section{REFERENCES}

[1] Allport, G. W. (1935). Attitudes. In Murchison C. (Ed.), Handbook of social psychology (pp. 798-844). Worcester, MA: Clark University Press.

[2] Breckler, S. J. \& Wiggins , E. C. (1991). Cognitive responses in persuasion: Affective and evaluation determinates. Jounals of Experimental Social Psychology, 27, 180-200.

[3] Dr. Kathryn Barker. (March 1999). futured Consulting Education Futurists, Quality guidelines for technologyassisted distance education. prepared for: Community Association for Community Education (CACE) and the Office of Learning Technologies (OLT) of Human Resources Development Canada (HRDC).

[4] Garrison, G. R. (1990). Understanding distance education: A framework for the future. London: Routledge.
[5] Hahn J. (2008), Mobile Learning for the Twenty - First Century Librarian. Reference Services Review, 36(3) ,(pp. 272-288).

[6] Holmberg, B. (1986). Growth and structure of distance education. Kent, England: Croom Helm.

[7] http://www.eoearth.org/article/Technological_innovation

[8] http://webserver.ignou.ac.in/NCIDE/Report250209.pdf.

[9] http://wiki.answers.com/Q/What_is_technology.

[10] http://wikieducator.org/Need_and_Importance_of_Infor mation_Technology_in_Education.

[11] http://www.col.org/pcf3/papers/pdfs/kuruba_gangappa.p df.

[12] John Bingham, Teresa Davis, Cathy Moore (2000) Emerging Technologies in Distance Learning. Issues Challenging Education. Retrieved from http://horizon.unc.edu/projects/issues/papers/Distance_L earning.html

[13] Le Roux, J. (1994) The Black Child In Crisis. A socioeducation perspective Volume2. J L Van Schaik.

[14] Morrison, J., (1996). Paradigm shifts. On the Horizon :Horizon List Archives - 4 Feb., 1996 [WWW document].

[15] Oblinger, D., \& Oblinger, J. (2005). Educating the Net Generation. the Web: EDUCAUSE E-Book, accessed from h t t p : / / w w w. ed u c a u se.edu.

[16] Ozgur, A. Z. (2007), Evaluating Audio Books as supported Course Materials in Distance Education: the experiences of the blind learners. The Turkish online Journal of Education Technology (TOJET), Volume (6), Issue (4), Article(2).

[17] Rekkedal, T. \& Dye, A. (2007). Mobile distance learning with PDAs: Development and testing of pedagogical and system solutions supporting mobile distance learners. International review of Research in Open and Distance Learning, 8, (2), pp. 1-21.

[18] Shaheen E. Lakhan and Kavita Jhunjhunwala (2008,p.2) Open Source Software in Education vol. 31, no. 2 EDUCAUSE 